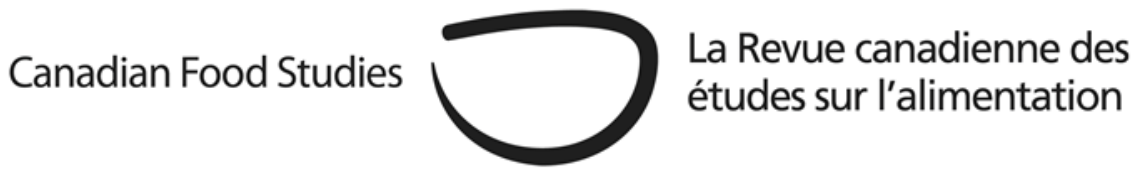

Perspective

\title{
"Ditch red meat and dairy, and don't bother with local food": The problem with dietary advice aiming to save the planet (and your health)
}

Ryan M Katz-Rosene*

University of Ottawa

\begin{abstract}
In recent years, there have been increasing calls for "global dietary transition" in order to save the planet and improve human health. One troubling development associated with this is the attempt to delineate in universal terms what constitutes a sustainable and healthy diet. In this article, I problematize an increasingly popular dietary narrative - one which calls for people to avoid red meat and dairy, and which portrays the local food movement as a romantic distraction. In contrast, I provide evidence for a range of sustainability and health benefits associated with localism and the inclusion of ruminants - the suborder of mammals from which humans derive most of their red meat and dairy - in the food system. Finally, using the neo-colonial subjugation of Indigenous food cultures as an example, I show how universal dietary advice can result in the promotion of culturally-inappropriate foods to the detriment of community health and sustainability. I conclude with a call for a more pluralist and multi-scalar approach to the multifaceted challenges associated with food production and consumption.
\end{abstract}

Keywords: Red meat; dairy; local food; sustainable diets; dietary transition 


\section{Introduction}

In recent years, domestic and international health and environmental authorities have increasingly called for a "global dietary transition" in order to tackle a number of current and foreseen challenges relating to the food system, including food insecurity, various forms of malnutrition, and environmental degradation linked to agricultural production (Searchinger et al., 2019). For instance, in 2019 the EAT-Lancet Commission introduced its "Planetary Health Diet" with the aim of "transforming eating habits, improving food production and reducing food waste" (EAT Forum, 2019). For its part the Government of Canada introduced its new food guide the same year (Government of Canada, 2019), proposing shifts to the content and proportions of food on the typical Canadian plate, as well as changes to how food is typically consumed. These are, in part, welcome interventions, as they help to illuminate the complex challenges faced by humanity within the food system inasmuch as prompting innovative responses. Nevertheless, in this perspective I take issue with one troubling development within the dietary transition literature - the attempt to promote a universal definition for what constitutes a "sustainable and healthy diet". Specifically, a powerful narrative has recently emerged that defines the latter as a diet which necessarily avoids red meat and dairy, and which further implies that local foods offer no real environmental or health benefits. In this article I offer a critique of this emergent narrative, arguing that the universal claims and dietary advice stemming from it are inappropriate given the existence of competing evidence and complexity seen within and between agricultural systems and food cultures around the world and particularly here in Canada. That is, there is absolutely no reason why a sustainable and healthy diet cannot include red meat and/or dairy and/or be founded upon locally-sourced foods. Moreover, we ought to be wary of the neocolonial character of universal dietary advice, given its potential to subjugate "other" food cultures and traditions, often to the detriment of community health and sustainability. I conclude by calling for more pluralist and multi-scalar responses to the variety of challenges faced within global food systems - one which supports all food producers and consumers who have genuine intentions of adopting more sustainable and healthier practices.

\section{A New Narrative}

The logic underlying the new narrative is founded on a set of robust global-scale peer-reviewed comparisons of the health impacts and environmental footprints associated with different foods (Clark et al., 2019; Poore \& Nemecek, 2018; Springmann et al., 2016). The underlying logic goes something like this: Data from global epidemiological studies show that the consumption of red meat and dairy is associated with a higher risk of cardiovascular disease (CVD) and diabetes than other common foods. Compilations of life-cycle assessments (LCAs) of different foods 
consistently show that red meat (beef in particular) and dairy are especially resource-intensive and emit higher amounts of greenhouse gases (GHGs) per kilogram of food produced than other protein-rich foods, in particular plant-based protein foods. Global LCA data also show that for most commodities, emissions from transportation only serve as a minimal portion of the overall footprint; rather it is emissions at the level of production which account for the greatest discrepancy between low-carbon and high-carbon variants of a given food. It stands to reason that if everyone changed their diet, replacing red meat and dairy for plant-based alternatives, and overcame biases about local food systems (favouring instead more 'efficient' alternatives sourced from global supply chains), the world would inevitably become healthier and more sustainable.

One of the most celebrated examples of this phenomenon is the aforementioned Planetary Health Diet proposed by the EAT-Lancet Commission. The Commission suggests it is "the optimal diet for people and planet" (EAT Forum, 2019 emphasis added). The proposed diet "largely consists of vegetables, fruits, whole grains, legumes, nuts, and unsaturated oils, includes a low to moderate amount of seafood and poultry, and includes no or a low quantity of red meat, processed meat, added sugar, refined grains, and starchy vegetables" (and further allows "moderate dairy consumption as an option"; Willett et al., 2019, pp. 485 and 459 emphasis added). While the study does not make specific reference to food miles, the authors note that unimpeded global trade in food commodities is preferable to a "food sovereignty" approach since the favouring of local food systems has led to increased environmental pressures (see p.465).

In short, the new narrative implies that any individual around the world can support their own health and planetary sustainability by removing red meat and dairy from their diet and replacing the latter with plant-based or perhaps other non-ruminant animal-based alternatives. Moreover, it implies that an individual who chooses to support local food systems on the assumption that it is better for the environment would be mistaken. Rather, it is highly-efficient global supply chains which ought to be supported for the sake of strengthening global sustainability, food security, and nutrition objectives for all. A recent widely-read blog published by data scientists at Our World in Data is characteristic of the universal advice stemming from the new narrative: "You can have a larger difference by focusing on what you eat, rather than 'eating local'," and "going 'red meat and dairy-free' (not totally meat-free) one day per week would achieve the same as having a diet with zero food miles" (Ritchie, 2020 emphasis added).

\section{The Problem(s)}

For this perspective I propose that the very idea of a universal diet is anathema to genuine socioecological sustainability and good health. I argue that while following the specific dietary claims outlined above may very well enable some individuals to reduce their environmental footprint or 
improve their health, it could equally be unsuccessful in other individual circumstances; for instance, in various geographical, cultural, or demographic contexts wherein red meat, dairy, or locally-produced foods make up a vital part of the community's diet, or where alternative forms of protein or imported foods are not readily accessible. Ultimately, a range of underlying contextual factors will determine whether the dietary advice is sound. The remainder of this article offers four main 'cracks' in the logical foundations of the new narrative, with particular attention to the Canadian context for food production and consumption.

\section{The broader benefits of local food systems}

Local food systems are portrayed as a romantic myth within the new narrative. Local food, it is suggested, is no better for the climate and will not protect people from food-related health problems. Worse, local production is small-scale, and in that sense does not help tackle global food insecurity. Local food systems are thus increasingly subjected to similar criticisms faced by organic food producers; namely, they are accused of being "inefficient" users of natural resources in a resource-constrained world, and for being no better for consumer health than conventional alternatives (for instance, Dangour et al., 2009; Treu et al., 2017). Yet by reducing the notion of sustainability and health to a crude assessment of average GHG footprints, or the statistical likelihood of developing CVD or diabetes, or the number of mouths fed per acre of production, the new narrative fails to incorporate numerous other factors within localized food systems that contribute to sustainability and good health (for a similar multi-dimensional defence of organic foods see Reganold \& Wachter, 2016).

After decades of a growing food sovereignty movement, it is clear that community-scale food systems do contribute to practices which support sustainability and good health. One indirect way they do this is by de-centralizing (and re-allocating) control over food production and consumption (Claeys, 2015; Wiebe et al., 2010). Farmer's markets, Community Shared Agriculture (CSA) projects, restaurants supporting local producers, etc. - all of these help to recirculate capital within a given community, in contrast to global food supply chains, which see a larger share of funds leaving their community of origin and concentrating in the hands of multinational corporations (Feenstra, 1997). These types of local food endeavours also help to build positive social relations in the community, which is particularly important in rural communities where food production makes up a larger share of the local economy (Wells et al., 1999).

In Canada, where there tends to be a divide between large industrial farms that typically cater to national-scale and international supply chains and smaller farms which typically supply local and regional foodsheds, the pressures to adopt different ecological management practices at the farm level are evident. Industrialized operations are far more likely to adopt "extractive" practices which have been associated with placing increased ecological pressures on soil, water, and biodiversity (IPBES, 2019). Meanwhile, local-scale projects are more likely to value 
"regenerative" practices which build soil carbon, protect water bodies and limit the impact on local wildlife (Qualman, 2019). ${ }^{1}$

In Canada, the growth of a range of locally-oriented "alternative food initiatives" (AFIs) should be celebrated for contributing to a growing network of increasingly informed actors seeking more sustainable, just, and healthy food structures (Desmarais \& Wittman, 2014; Levkoe, 2014; Sumner et al., 2014). To devalue AFIs merely because food miles make up a relatively small amount of the typical food footprint (or because well-functioning global supply chains are more "efficient") seems a narrow basis upon which to guide dietary choices for consumers everywhere.

\section{Problematic assumptions about protein interchangeability}

By comparing the environmental or health impacts of different foods on a per unit basis the new narrative provides a reductionist view of protein. It fails to account for the way that different proteins are made up of different chains of essential and non-essential amino acids and feature different "digestibility scores" (Bailey \& Stein, 2019). Moreover, animal sourced proteins and plant-based proteins are nutritionally inequivalent since they tend to be paired with different nutrients. For instance, the former often come alongside higher quantities of heme iron, vitamins B12 and D, and saturated fatty acids, whereas the latter typically come alongside higher quantities of dietary fibre, carbohydrates, and vitamin $\mathrm{C}$ (see Figure 1 as an example). This raises questions about what other health or ecological impacts might result from a one-to-one exchange of red meat and dairy with plant-based protein alternatives in a given diet.

\footnotetext{
1 This is not a hard and fast rule, of course. Some large-scale operations are turning to regenerative practices (particularly no-till crop production, which often requires expensive equipment).
} 
Figure 1: Nutrient comparison of 100 grams of beef and tofu

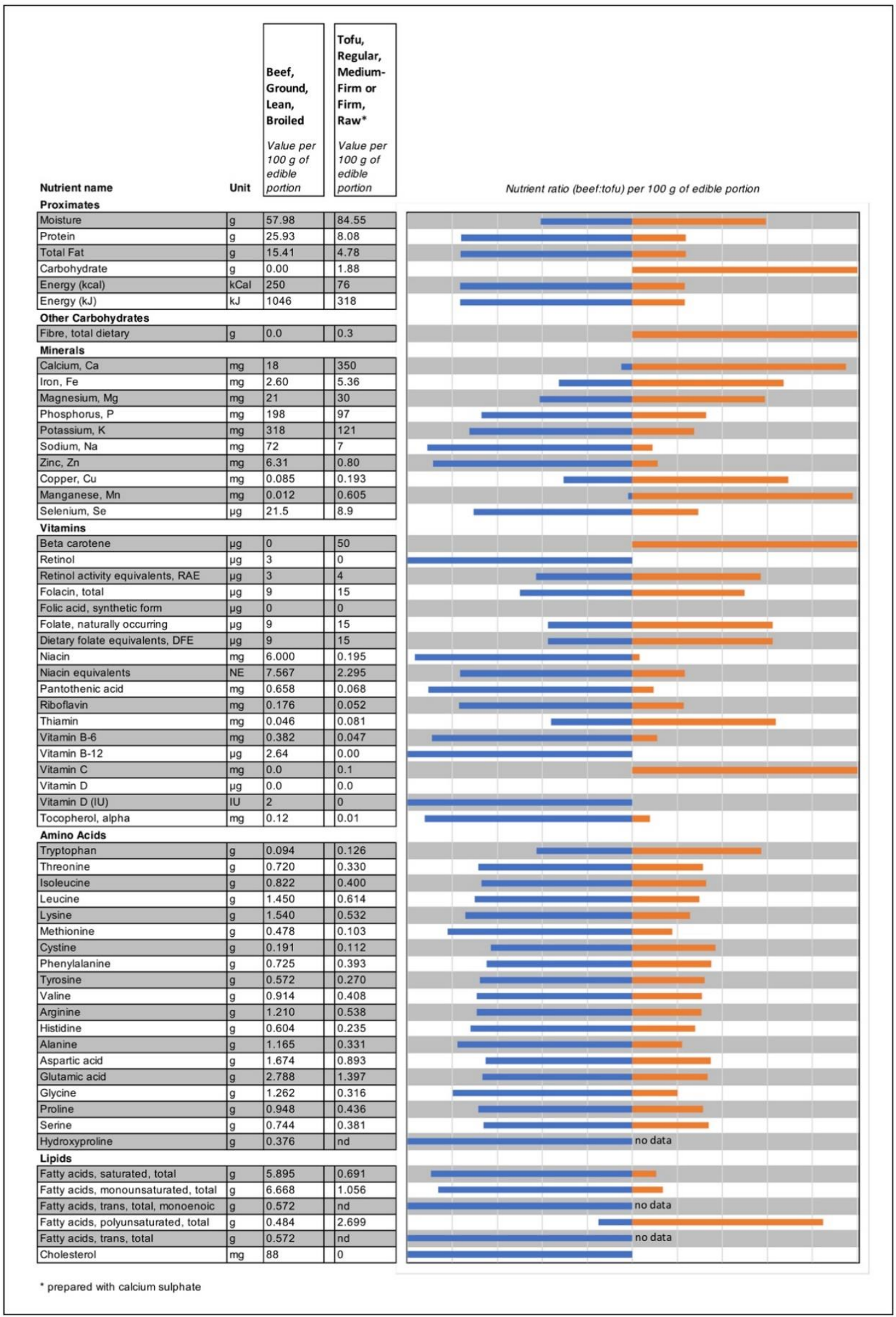

Data Source: Canadian Nutrient File, 2015 
For its part, red meat serves as a source of digestible "complete protein" (including all essential amino acids), which helps protect against deficiencies in globally challenging micronutrients (Leroy \& Cofnas, 2020). Similarly, all forms of dairy qualify as what the FAO defines as "excellent/high" quality sources of protein, particularly for children (which is not the case for most plant sources of protein used as dairy alternatives; Mathai et al., 2017). The point here is not to deny the possibility of achieving a nutritious and balanced diet without red meat and dairy, but rather to: a) emphasize how substantially different a meal featuring 100 grams of protein from red meat or dairy would be than one featuring exactly the same amount of protein from a plant-sourced alternative; and b) note that red meat and dairy are recognized as highlynutritious foods which can support good health.

In this sense, the new narrative's call to avoid red meat and dairy altogether could possibly have health-related consequences in some communities given the role played by these foods in supporting food security and nutrition (Mottet et al., 2017). It could even have unintended ecological implications if diets are levelized for protein quality, since - contrary to conventional wisdom - beef and milk production require less land than beans or peas when compared on an essential amino acid basis (Tessari et al., 2016). Even in a developed economy like Canada's, where per capita red meat consumption is much higher than the global average, new research has refuted the claim that reduced meat consumption results in improved health (Johnston et al., 2019). The saturated fatty acids found in animal based foods that concern those calling for avoiding red meat have recently begun to receive more nuanced attention from nutritionists who now suggest there may be a place for saturated fat within healthy diets after all (Alpert, 2020; Astrup et al., 2019, 2020). It is therefore inappropriate to call for universal adherence to a diet centered around avoiding these specific foods.

\section{The misuse of average global GHG footprint data}

There are four main reasons why global average GHG emissions values for ruminant-based foods tend to be relatively high, yet these same factors raise questions about what is being missed in terms of the potential these foods can play in sustainable agricultural systems.

First, ruminants emit a relatively high amount of methane as part of their digestive process and methane is a powerful GHG. However, recent high-level policy guidance hints at the dangers of measuring methane (a "flow" gas) in terms of equivalents of carbon dioxide (a "stock" gas), as this could lead to inaccurate assertions about the overall warming impact of ruminants (Lynch et al., 2020). When methane emissions are on a declining trend (on the order of $-0.3 \%$ per annum), the size of the methane sink will begin to outweigh the source after a period of about a decade, after which the net effect is one of cooling, not warming (Cain et al., 2019). This very trend has been observed in Canada over the last 12 years, suggesting the production of red meat and dairy in this country is having a negligible impact on methaneinduced warming (Katz-Rosene, 2020). 
Second, ruminants also have a very high average land use footprint, particularly in global terms since a considerable amount of forestland in Latin America is being converted to either cattle pasture or soy and maize production used for animal feed (Opio et al., 2013). Nevertheless, while it is true ruminants require more land per kilogram of food produced, it is a mistake to necessarily interpret this as "a form of inefficiency". Much of the world's agricultural land is perennial grassland (around 70\% according to the FAO, 2020) — an ecosystem which co-evolved alongside large herbivores. Arguably, one of the most sustainable forms of food production in a grassland is range-ecology including grazing herbivores, in contrast to crop production (especially tillage) that often erodes the soil and negatively impacts biodiversity. This is especially important in Canada's Prairie provinces (where about $80 \%$ of Canada's agricultural land is found), since holistically-managed cattle can play a key role in protecting this at-risk ecosystem (Gosnell et al., 2020; Pittman, 2018).

Third, LCAs of the GHG footprint of red meats do not always equitably share portions of the emissions profile with other non-edible products and services associated with ruminant production (such as hides, wool, fats, organs, milk, bone, serum, manure, draught power, etc.). When this is done, the food portion of the GHG footprint shrinks considerably (Opio et al., 2013, p. 173). Already the GHG intensity of beef and dairy is lower in Canada than the global averages (Legesse et al., 2016) — adequately sharing the emissions with the full range of byproducts would reduce Canadian values even further, though additional research is still required to determine more accurate estimates of the GHG footprint of Canadian beef and dairy when these factors are taken into account.

Finally, while some forms of ruminant management are able to draw down carbon dioxide into the soil (Teague et al., 2016), the process is immutably complex. As a result, many LCAs of beef and dairy do not sufficiently subtract the carbon dioxide removed from the atmosphere and sequestered into the soil from the GHG tally (see, for instance, the sensitivity analysis in Rotz et al., 2019). This results in relatively high footprint values for pasture-based foods in LCAs. Nevertheless, studies which have attempted to account for the potential soil sequestration of $\mathrm{CO} 2$ have found the latter to partially offset emissions from the grazing system, such that carefully managed grazing operations are viewed as a potential tool to support climate change mitigation efforts in the agricultural sector (Stanley et al., 2018; Wang et al., 2015).

In short, global LCA values for red meat and dairy, measured in CO2 equivalents, do not help inform Canadians about the actual climatic or ecosystemic impacts, or production contexts, of domestically-produced red meat and dairy, especially when consumers are purchasing locallyproduced meat or dairy from pasture-based systems, or when hunters are acquiring red meat from wild animals. 


\section{The neo-colonial character of universal dietary advice}

The Nyéléni Declaration on Food Sovereignty emphasizes the importance of cultural appropriateness of foods, and the rights of peoples "to define their own food and agricultural systems" (VIA Campesina, 2007). The assertion of authoritative knowledge about what foods are "best" (for one's health, for the environment, or any other reason) can therefore work against efforts to secure nutritious and sustainable food precisely because it lacks awareness of the broader contextual factors that shape food outcomes. In Canada, dietary guidance is particularly egregious when it reinforces neo-colonial relations between Indigenous peoples and "Western" authority structures (such as the state or institutionalized Eurocentric expert knowledge); yet the legacy of the subjugation of Indigenous food cultures also serves as an important reminder about the dangers of imposing any universalized wisdom upon others.

Canada has a dark history of colonialism and neo-colonialism with a traumatic legacy of impacts for Indigenous people. The Truth and Reconciliation Commission found that Canada's Aboriginal policy and the state's historical treatment of Indigenous peoples has operated as a form of cultural genocide (Amir, 2018). A significant component of this cultural genocide has been the erasure, devaluation, and subjugation of Indigenous food sovereignty and traditions, which in turn are frequently tied in with ecological and localized knowledge systems (Coté, 2016). In 2007, Health Canada introduced a companion document to Canada's food guide, with specific attention to First Nations, Inuit, and Métis communities, seeking to offer guidance to Indigenous peoples about proper nutrition. Yet this effort - in addition to lumping in all Indigenous peoples together despite vast cultural differences - has led to paternalist government programs (such as Nutrition North) that have sought to tackle food security and nutrition challenges through an imposed market-based Western approach (Mintz, 2019). The results have been disastrous, owing in part to the government's refusal to respect and support Indigenous food traditions and cultures (Chin-Yee \& Chin-Yee, 2015).

Pre-colonial food systems in the territory now known as Canada were highly diverse and regionally-specific. Fishing, trapping, hunting, gathering, harvesting, and cultivation were practiced to varying degrees in different Nations depending on local resource and climatic circumstances and cultural traditions. Dark meats high in saturated fats have tended to play a foundational role in many Indigenous food cultures, coming from a diverse array of animal sources, including bison, caribou, moose, deer (all of which are ruminants) — as well as bear, duck, goose, beaver, seal, etc. Dairy consumption, in contrast, was practically non-existent before colonization (Prosekov \& Ivanova, 2018). The universal dietary mantra to steer clear of red meat and approach local foods with environmental skepticism is thus largely antithetical to the traditional diets of most Indigenous communities in Canada (with advice on dairy being a moot point). Yet even if it were entirely complimentary it would still be problematic to propose a universal diet for one and all; the point here is to recognize the inherent danger of devaluing a given community's cultural food practices, and consequently the role that local knowledge and 
culturally-appropriate foods can play in community-based nutrition and ecosystem management (see Milburn, 2004).

A greater appreciation for the range of unique contextual factors involved in nutrition and food sustainability is required - including attention to food combinations within different dietary traditions, broader consumption habits and practices, and a host of geographical and regionallyspecific conditions. To assert that the localized cultural context of food is inconsequential to health and sustainability is to follow in the footsteps of a colonial mindset which has been shown to have unjust and unfavourable consequences.

\section{Towards a pluralist multi-scalar approach}

Humanity faces a number of challenges relating to the food system: Food production contributes to climate change and biodiversity decline; there are stark inequities between and within different regions in terms of secure access to culturally-appropriate food; and there is presently a "double-burden" of malnutrition, wherein some parts of the world lack basic nutrients while other corners see an overconsumption of unhealthy foods (Canales Holzeis et al., 2019). Such a complex and multi-faceted problem requires an equally nuanced response, wherein different approaches that seek to address aspects of the challenge in specific places ought to be supported, or at least given a chance. In this sense there is wisdom in supporting a multitude of approaches to healthy food and sustainable agricultural systems, as a more diverse set of approaches contributes to greater resiliency, being more inclusive to an array of food cultures.

This perspective has offered a critique of universal claims about what does or does not qualify as "healthy and sustainable" food, particularly as envisioned by an emergent and increasingly popular global narrative that singles-out red meat, dairy, and local food systems. While the diet proposed by the new narrative may qualify as a useful way for a given individual to adopt a healthy and sustainable lifestyle, the underlying narrative's claim to universality is flawed because there are instances where some of its underlying claims do not stand up to scrutiny. This perspective has highlighted four categories of problems with the underlying narrative: First, its targeting of local food systems fails to account for many social, economic, and public health benefits associated with the support of community-scale food structures. Second, the narrative's treatment of different protein-source foods as interchangeable serves as a reductionist interpretation of this essential macronutrient. Third, the global LCA footprint data used as evidence for the high environmental costs of red meat and dairy do a very poor job of contextualizing the broader ecological influence of ruminants in different places, particularly in a Canadian context. And finally, through its neo-colonial approach, universal dietary advice negates the value of culture and traditional localized knowledge in supporting healthy and sustainable food systems. Food studies scholars ought to cultivate awareness about the complexities in the food system; about diverse approaches to production and consumption owing 
to different cultures, places, and local traditions; and about the beauty and resilience of diversity — not make generalized claims about which specific foods to avoid based on their origins or type.

\section{References}

Alpert, J. S. (2020). The great meat debate. The American Journal of Medicine, 133(7), 769-770. https://doi.org/10.1016/j.amjmed.2020.02.002

Amir, R. (2018). Cultural genocide in Canada? It did happen here. Aboriginal Policy Studies, 7(1), Article 1. https://doi.org/10.5663/aps.v7i1.28804

Astrup, A., Bertram, H. C., Bonjour, J.-P., Groot, L. C. de, Otto, M. C. de O., Feeney, E. L., Garg, M. L., Givens, I., Kok, F. J., Krauss, R. M., Lamarche, B., Lecerf, J.-M., Legrand, P., McKinley, M., Micha, R., Michalski, M.-C., Mozaffarian, D., \& Soedamah-Muthu, S. S. (2019). WHO draft guidelines on dietary saturated and trans fatty acids: Time for a new approach? BMJ, 366, 14137. https://doi.org/10.1136/bmj.14137

Astrup, A., Magkos, F., Bier, D. M., Brenna, J. T., de Oliveira Otto, M. C., Hill, J. O., King, J. C., Mente, A., Ordovas, J. M., Volek, J. S., Yusuf, S., \& Krauss, R. M. (2020). Saturated fats and health: A reassessment and proposal for food-based recommendations: JACC State-of-the-Art Review. Journal of the American College of Cardiology, 76(7), 844-857. https://doi.org/10.1016/j.jacc.2020.05.077

Bailey, H. M., \& Stein, H. H. (2019). Can the digestible indispensable amino acid score methodology decrease protein malnutrition. Animal Frontiers, 9(4), 18-23. https://doi.org/10.1093/af/vfz038

Cain, M., Lynch, J., Allen, M. R., Fuglestvedt, J. S., Frame, D. J., \& Macey, A. H. (2019). Improved calculation of warming-equivalent emissions for short-lived climate pollutants. Npj Climate and Atmospheric Science, 2(1), 29. https://doi.org/10.1038/s41612-019-00864

Canales Holzeis, C., Fears, R., Moughan, P. J., Benton, T. G., Hendriks, S. L., Clegg, M., ter Meulen, V., \& von Braun, J. (2019). Food systems for delivering nutritious and sustainable diets: Perspectives from the global network of science academies. Global Food Security, 21, 72-76. https://doi.org/10.1016/j.gfs.2019.05.002

Chin-Yee, M., \& Chin-Yee, B. H. (2015). Nutrition North Canada: Failure and facade within the northern strategy. University of Toronto Medical Journal, 92(3), 13-18.

Claeys, P. (2015). Human rights and the food sovereignty movement: Reclaiming control. Routledge.

Clark, M. A., Springmann, M., Hill, J., \& Tilman, D. (2019). Multiple health and environmental impacts of foods. Proceedings of the National Academy of Sciences, 116(46), 23357-23362 https://doi.org/10.1073/pnas.1906908116 
Coté, C. (2016). "Indigenizing" food sovereignty. Revitalizing Indigenous food practices and ecological knowledges in Canada and the United States. Humanities, 5(3), 57. https://doi.org/10.3390/h5030057

Dangour, A. D., Dodhia, S. K., Hayter, A., Allen, E., Lock, K., \& Uauy, R. (2009). Nutritional quality of organic foods: A systematic review. The American Journal of Clinical Nutrition, 90(3), 680-685. https://doi.org/10.3945/ajcn.2009.28041

Desmarais, A. A., \& Wittman, H. (2014). Farmers, foodies and First Nations: Getting to food sovereignty in Canada. The Journal of Peasant Studies, 41(6), 1153-1173. https://doi.org/10.1080/03066150.2013.876623

EAT Forum. (2019, February 11). The Planetary Health Diet. EatForum.Org. https://eatforum.org/learn-and-discover/the-planetary-health-diet/

Feenstra, G. (1997). Local food system and sustainable communities. American Journal of Alternative Agriculture, 12(1), 28-36. https://doi.org/10.1017/S0889189300007165

Food and Agriculture Organization. (2020). Are grasslands under threat? FAO.Org. http://www.fao.org/uploads/media/grass_stats_1.pdf

Gosnell, H., Charnley, S., \& Stanley, P. (2020). Climate change mitigation as a co-benefit of regenerative ranching: Insights from Australia and the United States. Interface Focus, 10(5), 20200027. https://doi.org/10.1098/rsfs.2020.0027

Government of Canada. (2019, January 21). Canada's food guide. Food-Guide.Canada.Ca. https://food-guide.canada.ca/en/

IPBES. (2019). Summary for policymakers of the global assessment report on biodiversity and ecosystem services of the Intergovernmental Science-Policy Platform on Biodiversity and Ecosystem Services. IPBES secretariat. https://www.ipbes.net/system/tdf/ipbes_7_10_add1-_advance_0.pdf?file $=1 \&$ type $=$ node $\&$ id $=35245$

Johnston, B. C., Zeraatkar, D., Han, M. A., Vernooij, R. W. M., Valli, C., El Dib, R., Marshall, C., Stover, P. J., Fairweather-Taitt, S., Wójcik, G., Bhatia, F., de Souza, R., Brotons, C., Meerpohl, J. J., Patel, C. J., Djulbegovic, B., Alonso-Coello, P., Bala, M. M., \& Guyatt, G. H. (2019). Unprocessed red meat and processed meat consumption: Dietary guideline recommendations from the nutritional recommendations (NutriRECS) consortium. Annals of Internal Medicine, 171(10), 756-764. https://doi.org/10.7326/M19-1621

Katz-Rosene, R. (2020, April 13). The climate case for moderate beef and dairy consumption. Policy Options. https://policyoptions.irpp.org/magazines/april-2020/the-climate-case-formoderate-beef-and-dairy-consumption/

Legesse, G., Beauchemin, K. A., Ominski, K. H., McGeough, E. J., Kroebel, R., MacDonald, D., Little, S. M., \& McAllister, T. A. (2016). Greenhouse gas emissions of Canadian beef production in 1981 as compared with 2011. Animal Production Science, 56(3), 153-168. https://doi.org/10.1071/AN15386

Leroy, F., \& Cofnas, N. (2020). Should dietary guidelines recommend low red meat intake? Critical Reviews in Food Science and Nutrition, 60(16), 2763-2772. https://doi.org/10.1080/10408398.2019.1657063 
Levkoe, C. Z. (2014). The food movement in Canada: A social movement network perspective. The Journal of Peasant Studies, 41(3), 385-403. https://doi.org/10.1080/03066150.2014.910766

Lynch, J., Cain, M., Pierrehumbert, R., \& Allen, M. (2020). Demonstrating GWPlast: A means of reporting warming-equivalent emissions that captures the contrasting impacts of shortand long-lived climate pollutants. Environmental Research Letters, 15(4), 044023. https://doi.org/10.1088/1748-9326/ab6d7e

Mathai, J. K., Liu, Y., \& Stein, H. H. (2017). Values for digestible indispensable amino acid scores (DIAAS) for some dairy and plant proteins may better describe protein quality than values calculated using the concept for protein digestibility-corrected amino acid scores (PDCAAS). British Journal of Nutrition, 117(4), 490-499. https://doi.org/10.1017/S0007114517000125

Milburn, M. P. (2004). Indigenous nutrition: Using traditional food knowledge to solve contemporary health problems. American Indian Quarterly, 28(3/4), 411-434. JSTOR.

Mintz, C. (2019, March 12). The history of food in Canada is the history of Colonialism. The Walrus. https://thewalrus.ca/the-history-of-food-in-canada-is-the-history-of-colonialism/

Mottet, A., de Haan, C., Falcucci, A., Tempio, G., Opio, C., \& Gerber, P. (2017). Livestock: On our plates or eating at our table? A new analysis of the feed/food debate. Global Food Security, 14, 1-8. https://doi.org/10.1016/j.gfs.2017.01.001

Opio, C., Gerber, P. J., Mottet, A., Falcucci, A., Tempio, G., MacLeod, M., Vellinga, T., Henderson, B., \& Steinfeld, H. (2013). Greenhouse gas emmission from ruminant supply chains-A global life cycle assessment. Food and Agricultural Organization of the United Nations. http://www.fao.org/3/i3461e/i3461e.pdf

Pittman, J. (2018, July 24). How cattle ranching can help preserve species at risk in Canada's grasslands. Canadian Geographic. https://www.canadiangeographic.ca/article/how-cattleranching-can-help-preserve-species-risk-canadas-grasslands

Poore, J., \& Nemecek, T. (2018). Reducing food's environmental impacts through producers and consumers. Science, 360(6392), 987-992. https://doi.org/10.1126/science.aaq0216

Prosekov, A. Y., \& Ivanova, S. A. (2018). Nutritional features of indigenous people of Siberia and North America: Are we relatives? Journal of Ethnic Foods, 5(3), 155-160. https://doi.org/10.1016/j.jef.2018.07.002

Qualman, D. (2019). Tackling the farm crisis and the climate crisis: A transformative strategy for Canadian farms and food systems. National Farmers Union. https://www.nfu.ca/wpcontent/uploads/2020/01/Tackling-the-Farm-Crisis-and-the-Climate-Crisis-NFU-2019.pdf

Reganold, J. P., \& Wachter, J. M. (2016). Organic agriculture in the twenty-first century. Nature Plants, 2(2), 1-8. https://doi.org/10.1038/nplants.2015.221

Ritchie, H. (2020, January 24). You want to reduce the carbon footprint of your food? Focus on what you eat, not whether your food is local. Our World in Data.

https://ourworldindata.org/food-choice-vs-eating-local 
Rotz, C. A., Asem-Hiablie, S., Place, S., \& Thoma, G. (2019). Environmental footprints of beef cattle production in the United States. Agricultural Systems, 169, 1-13. https://doi.org/10.1016/j.agsy.2018.11.005

Searchinger, T., Waite, R., Hanson, C., \& Ranganathan, J. (2019). Creating a sustainable food future. World Resources Institute. https://wrr-food.wri.org/sites/default/files/201907/WRR_Food_Full_Report_4.pdf

Springmann, M., Godfray, H. C. J., Rayner, M., \& Scarborough, P. (2016). Analysis and valuation of the health and climate change cobenefits of dietary change. Proceedings of the National Academy of Sciences, 113(15), 4146-4151. https://doi.org/10.1073/pnas.1523119113

Stanley, P. L., Rowntree, J. E., Beede, D. K., DeLonge, M. S., \& Hamm, M. W. (2018). Impacts of soil carbon sequestration on life cycle greenhouse gas emissions in Midwestern USA beef finishing systems. Agricultural Systems, 162, 249-258. https://doi.org/10.1016/j.agsy.2018.02.003

Sumner, J., McMurtry, J. J., \& Renglich, H. (2014). Leveraging the local: Cooperative food systems and the local organic food co-ops network in Ontario, Canada. Journal of Agriculture, Food Systems, and Community Development, 4(3), 47-60-47-60. https://doi.org/10.5304/jafscd.2014.043.004

Teague, W. R., Apfelbaum, S., Lal, R., Kreuter, U. P., Rowntree, J., Davies, C. A., Conser, R., Rasmussen, M., Hatfield, J., Wang, T., Wang, F., \& Byck, P. (2016). The role of ruminants in reducing agriculture's carbon footprint in North America. Journal of Soil and Water Conservation, 71(2), 156-164. https://doi.org/10.2489/jswc.71.2.156

Tessari, P., Lante, A., \& Mosca, G. (2016). Essential amino acids: Master regulators of nutrition and environmental footprint? Scientific Reports, 6(1), 1-13. https://doi.org/10.1038/srep26074

Treu, H., Nordborg, M., Cederberg, C., Heuer, T., Claupein, E., Hoffmann, H., \& Berndes, G. (2017). Carbon footprints and land use of conventional and organic diets in Germany. Journal of Cleaner Production, 161, 127-142. https://doi.org/10.1016/j.jclepro.2017.05.041

VIA Campesina. (2007, February 27). Declaration of Nyéléni. Nyeleni.Org. https://nyeleni.org/spip.php?article290

Wang, T., Teague, W. R., Park, S. C., \& Bevers, S. (2015). GHG mitigation potential of different grazing strategies in the United States southern Great Plains. Sustainability, 7(10), 1350013521. https://doi.org/10.3390/su71013500

Wells, B., Gradwell, S., \& Yoder, R. (1999). Growing food, growing community: Community Supported Agriculture in rural Iowa. Community Development Journal, 34(1), 38-46. https://doi.org/10.1093/cdj/34.1.38

Wiebe, N., Desmarais, A. A., \& Wittman, H. (2010). Food sovereignty: Reconnecting food, nature \& community. Fernwood. 
Willett, W., Rockström, J., Loken, B., Springmann, M., Lang, T., Vermeulen, S., Garnett, T., Tilman, D., DeClerck, F., Wood, A., Jonell, M., Clark, M., Gordon, L. J., Fanzo, J., Hawkes, C., Zurayk, R., Rivera, J. A., Vries, W. D., Sibanda, L. M., .. Murray, C. J. L. (2019). Food in the Anthropocene: The EAT-Lancet Commission on healthy diets from sustainable food systems. The Lancet, 393(10170), 447-492.

https://doi.org/10.1016/S0140-6736(18)31788-4 